СКАЛОЗУБ В. В., доктор технічних наук, професор,

ОЧКАСОВ О. Б., кандидат технічних наук, доцент,

КІБЕЦЬ Д. В., магістр

(Дніпровський національний університет залізничного транспорту імені академіка

В. Лазаряна)

\title{
Автоматизований експертний комплекс із дослідження та прогнозування параметрів силових енергетичних установок локомотивів
}

У статті досліджено можливості створення та результати застосування автоматизованого експертного комплексу, призначеного для вирімення завдань з удосконалення процесів експлуатації парків локомотивів, що реалізується засобами сучасних інтелектуальних систем. Прочедури моніторингу та діагностування забезпечують реалізаџію завдань контролю параметрів функціонування силових енергетичних установок локомотивів (СЕУЛ). Комплекс експертної системи (КЕС-СЕУЛ) реалізує базові завдання щзодо побудови системи аналізу, діагностування та прогнозування стану СЕУЛ на основі сигналів кутової швидкості обертів колінчатих валів. У КЕС-СЕУЛ завдання експертизи реалізуються шляхом поєднання методів ичифрової обробки сигналів, статистичного аналізу, класифікачії та використання емпіричних знань експертів. Подано структуру, моделі та результати діагностування СЕУЛ.

Ключові слова: силова енергетична установка, локомотив, кутова ивидкість обертів, колінчатий вал, інтелектуальні автоматизовані системи, діагностування, прогнозування, логістична регресія.

\begin{abstract}
Постановка проблеми
Підвищення ефективності автоматизованої експлуатації широкого кола технолого-економічних процесів (ТЕП) та технічних систем (ТС) залишається одним із пріоритетних завдань залізничного транспорту України (ЗТУ). Сучасним і актуальним напрямком щодо вирішення цього завдання є розробка та запровадження залізничних інтелектуальних систем (3IC) $[1,2,3]$. Цьому напрямку досліджень відповідає завдання щодо удосконалення автоматизації процесів експлуатації парків локомотивів шляхом впровадження сучасних інтелектуальних моніторингових систем, призначених для контролю функціонування складних технічних об'єктів, зокрема силових енергетичних установок локомотивів (СЕУЛ). Реалізація такого завдання 3 автоматизації процесів технічного обслуговування тягового рухомого складу (ТРС) дозволить зменшити час перебування локомотивів у ремонті, а в перспективі - перейти від планово-запобіжної системи обслуговування до обслуговування за фактичним технічним станом. Необхідно зазначити, що останніми роками при діагностуванні ТРС все більш актуальною стає стратегія розробки та впровадження систем нерозбірного діагностування тепловозних двигунів. Одним із способів реалізації цієї стратегії $є$ метод
\end{abstract}

нерозбірного діагностування та контролю технічного стану силових енергетичних установок локомотивів (СЕУЛ), зокрема двигунів тепловозів, на основі вимірів нерівномірності кутової швидкості обертання колінчатих валів під час роботи.

Змістовно завдання щодо формування експертних комплексів КЕС-СЕУЛ реалізується шляхом поєднання методів цифрової обробки сигналів, статистичного аналізу, класифікації і використання емпіричних знань експертів. В основу розробки КЕССЕУЛ покладено положення, що кутова швидкість колінчатого вала дизеля в межах робочого циклу не постійна, а іiі коливання має вплив на обмежений набір показників. Сутність методу полягає в знятті часу оберту 3 високою дискретизацією за допомогою під'єднаного до колінчатого вала цифрового пристрою, що виконує реєстрацію часу проходження валом певного кута. Через те що чинників, які мають вплив та відображаються на кутовій швидкості, досить багато, такий метод придатний i може вказати на значну кількість відхилень у роботі двигунів. 


\begin{abstract}
Аналіз досліджень

Питанням щодо можливості створення

уніфікованих та універсальних інтелектуальних автоматизованих систем (IАCУ) залізничного транспорту, 3 використанням уже існуючих високоефективних автоматизованих систем управління (АСУ), приділена значна увага у багатьох дослідженнях [3 - 5]. Зокрема, встановлені можливості створення IACУ на основі платформи аналітичних серверів та онтологічних систем, призначених для підтримки потужних методів моделювання складних технологій i систем, a також функціонування удосконалених онтологій АСУ, що розширюються та еволюціонують [6 - 8]. Для запропонованої платформи аналітичних серверів було також розроблено приклад формалізації та реалізації уніфікованих завдань діагностування характеристик виробничих процесів 3 нечіткими параметрами [4]. При цьому зазначено, що «до інформаційних структур автоматизованих систем У3, зокрема системи АСК ВП УЗ-С, можуть бути вбудовані практично всі технологічні процеси роботи вантажного залізничного транспорту, а також інші технології експлуатації об'єктів УЗ, в тому числі завдання зі створення інтелектуальних систем транспорту» [1, 2, 4]. Система АСК ВП УЗ-С автоматизує широкий спектр завдань, які раніше вирішувалися окремими АСУ на різноманітних технологічних і технічних платформах. У перспективі поданий у статті експертний комплекс КЕС-СЕУЛ також може увійти до платформи аналітичних серверів ЗТУ.
\end{abstract}

Для вирішення завдань діагностування станів об'єктів парків технічних систем (ТС) у ряді статей також застосовують уніфіковані процедури класифікації. У роботі [3] вирішено завдання 3 оптимального управління процесами експлуатації парків стрілочних електричних двигунів (ЕД). При цьому були ураховані умови невизначеності, які можливо представити у формі нечітких величин [2, 9]. Завдання автоматизації процесів експлуатації вирішено на основі створення інтелектуальної технології контролю парку за поточним станом ЕД. Тут засоби діагностування побудовано на аналізі даних моніторингу параметрів частотного спектра робочого струму двигуна, а отримання спектральних характеристик струму ЕД реалізовано за допомогою швидкого перетворення Фур'є [10, 11, 24]. Для кожного електродвигуна формується індивідуальна модель (IM), в якій накопичуються і зберігаються поточні характеристики справного стану двигуна. При їх зіставленні отримують оцінки достовірності виявлених несправностей ЕД. Наведена загальна концепція інтелектуального управління експлуатацією парків ЕД може бути застосована зокрема для моніторингу та діагностування СЕУЛ, у цілому парків TPC [2].
При формуванні структури та визначенні базових процедур КЕС-СЕУЛ було проведено широкий аналіз досліджень, спрямованих на достовірне та ефективне відображення процесів у СЕУЛ, на основі сигналів кутової швидкості обертів колінчатого вала. Такі дані мають давати змогу встановити можливі та необхідні для управління процесами експлуатації стани двигунів, а також забезпечать однозначну класифікацію та прогнозування змін станів на певний період.

Слід зазначити, що при дослідженнях вимірюваних сигналів обертання колінчатих валів використовувалися різноманітні методи виділення ознак нерівномірності кутової швидкості обертання $[12,13]$. Так, для отримання необхідних ознак станів СЕУЛ було застосовано методи фільтрування, трансформації Фур'є, згортки, визначення статистичних та сигнальних оцінок $[10,15,16]$. Результати досліджень у цілому дозволили встановити та виконувати класифікацію станів енергетичних установок локомотивів 3 досить високою точністю. Подальшими завданнями досліджень були формування баз знань експертних систем класифікації станів [24], моделей регресіі, зокрема логістичних, та інших призначених для класифікації станів двигунів на підставі значень обраних ознак (наприклад, аналіз спектрів - величини інтенсивності частот у заданих діапазонах [2, 3]). Для формування моделей класифікації станів двигунів використовують різноманітні методи, а результати моделювання в подальшому були інтерпретовані, щоб встановити значущість певних характеристик сигналів, стосовно завдань класифікації. У разі отримання встановлених оцінок достовірності класифікації станів СЕУЛ, сформовані моделі регресії використовують для побудови баз знань експертних систем діагностування станів ТРС. У ряді досліджень також було розглянуто методи корекції помилок класифікації, що забезпечило можливість підвищення експлуатаційної надійності системи прогнозування станів ТРС. В деяких статтях визначають можливості застосування моделей класифікації для оптимізації показників економічних і часових витрат для аналізу характеристик процесів експлуатації.

\section{Сутність не вирішених раніше завдань створення КЕС-СЕУЛ}

Проведений аналіз показав актуальність завдання щодо створення автоматизованого експертного комплексу з дослідження та прогнозування параметрів СЕУЛ. На сьогодні недослідженими залишилися питання щодо використання для такого комплексу сигналів, які відбивають нерівномірності обертання колінчатих валів. При цьому актуальними $є$ питання стосовно використання таких даних і відповідних засобів для забезпечення можливості проведення моніторингу, удосконалення процедур експлуатації 
вузлів ТРС, а також для автоматизації формування ефективних моделей класифікації станів двигунів, визначення її придатності для формування та розвитку КЕС-СЕУЛ. Для вирішення таких завдань необхідно сформувати засади та методи вимірювання сигналів, які характеризують нерівномірності обертання колінчатих валів, основні структури та процедури моніторингу процесів експлуатації ТРС, функції та процедури автоматизованого експертного комплексу з дослідження та прогнозування параметрів СЕУЛ, розробити автоматизований конвеєр формування моделей класифікації станів двигунів, а також програмні засоби щодо створення та розвитку КЕССЕУЛ.

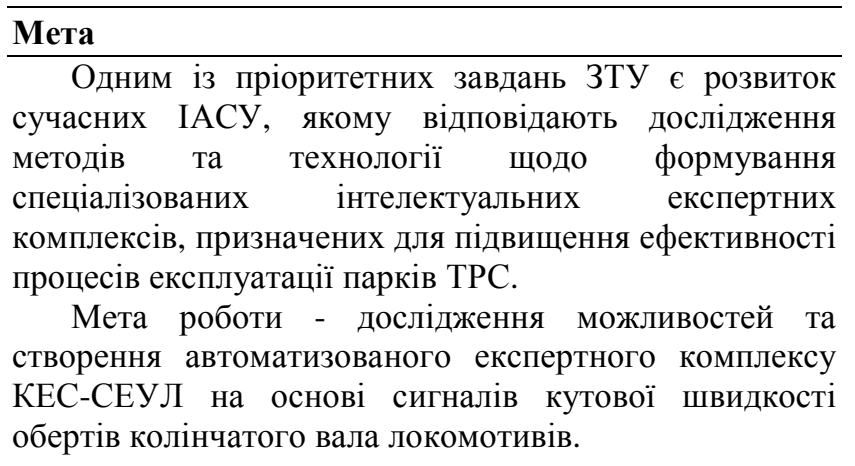

Процедури отримання та оброблення даних кутової швидкості колінчатого вала СЕУЛ

Для отримання показників нерівномірності обертання колінчатого вала локомотива, сигналів, необхідно 3 високим ступенем дискретизації зняти показники часу його «провороту» на незначний кут. У роботі дані були зняті диференціальним датчиком Холла, що під'єднувався до колінчатого вала дизельного двигуна (КВД). Датчик встановлено на торцевій частині колінчатого вала дизеля Д50 з боку генератора або привода масляного насоса. На

Рис. 1 зображено схему встановлення датчика [12]. Прилад знімає дані про різницю часу проходження впадини між зубцями шестірні датчика 3 високою точністю (мілісекунди), але не дозволяє встановити, якій фазі двигуна відповідає певний часовий показник. Пристрій записував 625 часових проміжків при одному оберті двигуна, що достатньо для дизельного двигуна 3 шістьма циліндрами (фіксувався час проходження кута 0.576 градусів). Д50 є чотиритактним двигуном, тобто прохід повного робочого циклу відбувався за два оберти та запису пакета з 1250 часових показників.

Для представлення експериментальних даних та опису станів двигуна пакети записувалися до CSV (comma separated values) файлів, які іменувалися порядковими номерами робочих циклів експериментів. У табл. 1 наведено змодельовані стани двигуна Д50 і їх кодування.

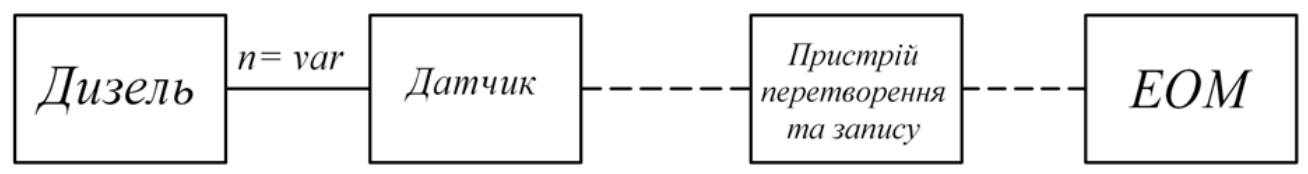

Рис. 1. Структура пристрою реєстрування сигналів КВД

Таблиця 1

Змодельовані стани двигуна і їх кодування КЕС-СЕУЛ

\begin{tabular}{|l|l|}
\hline \multicolumn{1}{|c|}{ Стан двигуна } & \multicolumn{1}{c|}{ Код стану } \\
\hline несправність у першому циліндрі через відсутність згоряння & cylinder_1st_off_is0 \\
\hline несправність у першому циліндрі через відкриття клапана & cylinder_1st_off_is1 \\
\hline несправність у другому циліндрі через відсутність згоряння & cylinder_2nd_off_is0 \\
\hline несправність у другому циліндрі через відкриття клапана & cylinder_2nd_off_is1 \\
\hline несправність у третьому циліндрі через відсутність згоряння & cylinder_3rd_off_is0 \\
\hline несправність у четвертому циліндрі через відсутність згоряння & cylinder_4th_off_is0 \\
\hline несправність у четвертому циліндрі через відкриття клапана & cylinder_4th_off_is1 \\
\hline несправність у п’ятому циліндрі через відсутність згоряння & cylinder_5th_off_is0 \\
\hline несправність у шостому циліндрі через відсутність згоряння & cylinder_6th_off_is0 \\
\hline несправність у шостому циліндрі через відкриття клапана & cylinder_6th_off_is1 \\
\hline робочий стан & good_300kWt \\
\hline робочий стан на потужності 300 кВт & good \\
\hline
\end{tabular}


Для формування вихідних даних експертної системи було необхідно визначити ознаки станів i моделі для їх відображення в програмі. Побудова узагальнюючих функцій на всіх вибірках експериментальних даних виконана 3 використанням моделей машинного навчання [19, 20]. На Рис. показано статистичні відмінності часових показників у сигналах різних станів двигуна Д50, які мають суттєво різні розподіли. Графічний вигляд сигналів для різних станів СЕУЛ наведено на рис. 3.

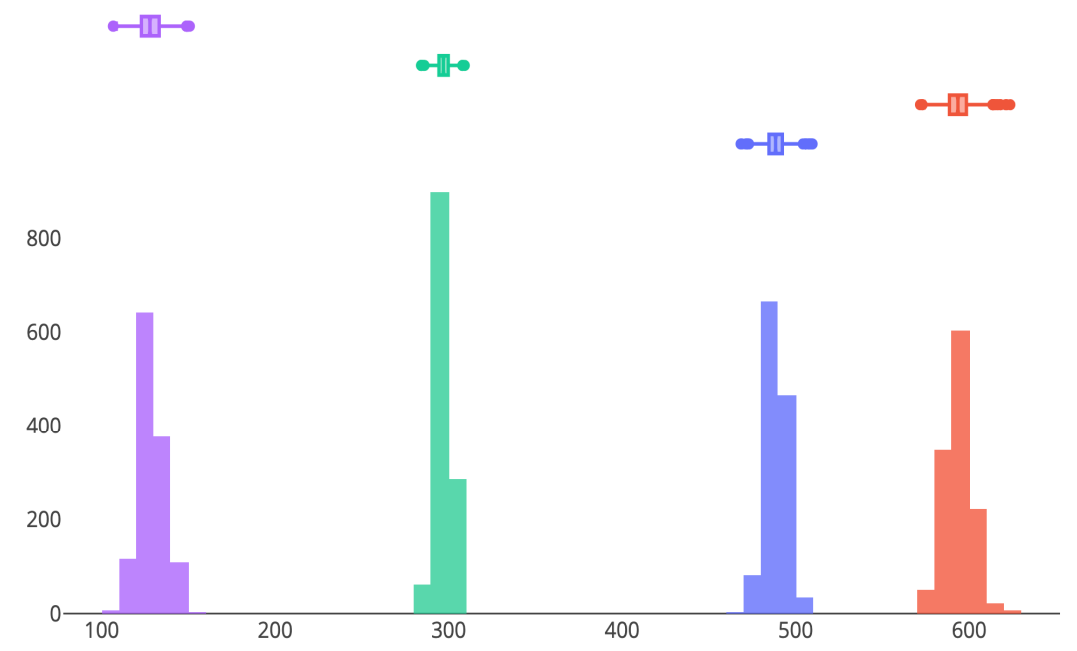

Рис. 2. Гістограми розподілу значень часу для різних класів (зліва направо: cylinder_1st_off_is1, cylinder_1st_off_is0,good_300kWt, good)
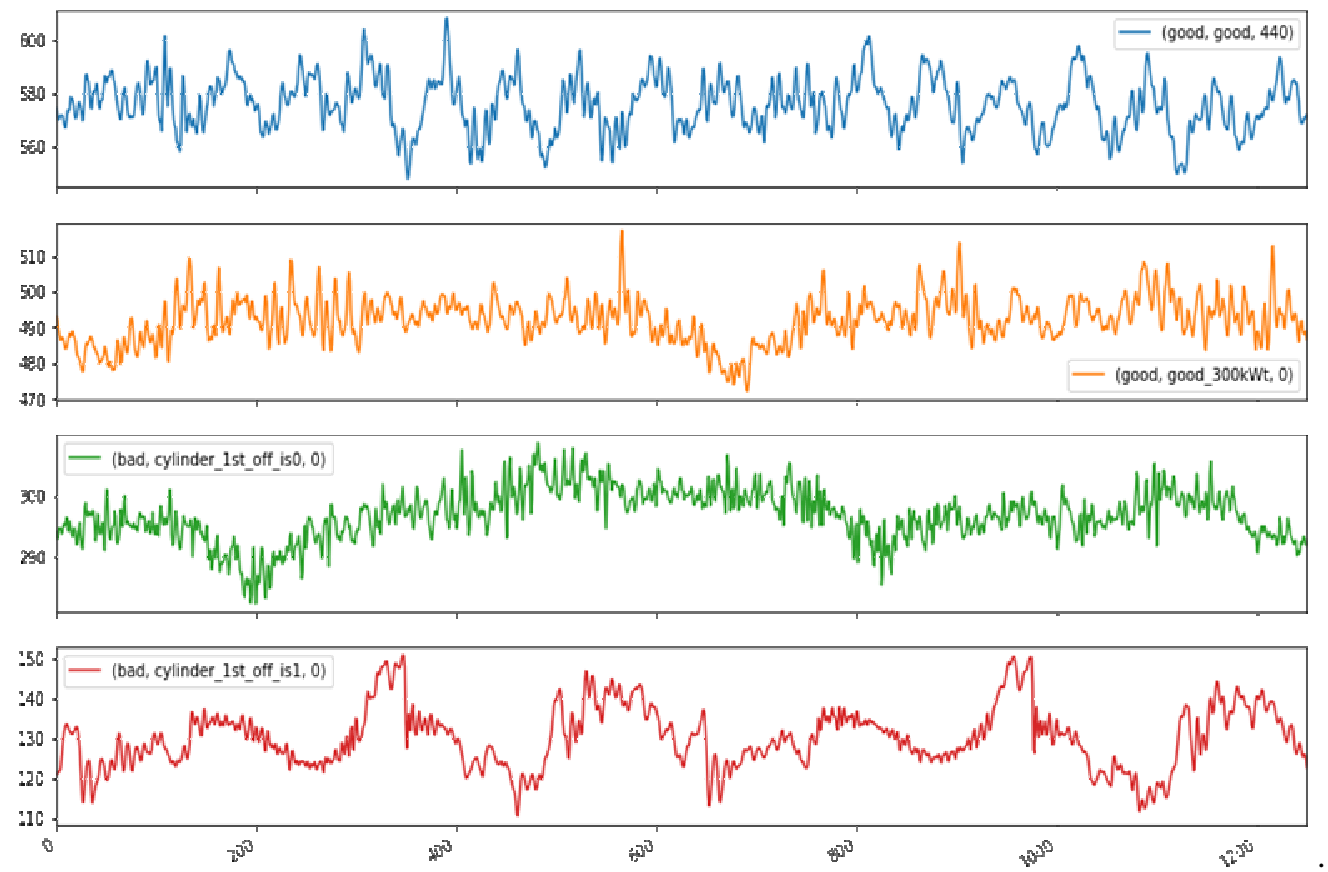

Рис. 3. Сигнали різних станів двигуна

Формування бази знань для аналізу стану двигуна за кутовим прискоренням колінчатого вала на основі спектрального аналізу

При створенні програмного комплексу КЕС-СЕУЛ були досліджені різноманітні відомі методи виділення ознак нерівномірності кутової швидкості обертання колінчатого вала на основі вимірюваних сигналів [14, 15]. Серед цих багатьох досліджених методів були відібрані такі, на основі яких можливо виконати класифікацію станів СЕУЛ з досить високої точністю. Для отримання необхідних ознак станів СЕУЛ у програмному комплексі застосовані методи 
фільтрування, трансформації Фур'є, згортки, визначення статистичних та сигнальних оцінок [11, 19]. Застосовані математичні алгоритми відповідають сучасним методам для вирішення задач виділення ознак із сигналів таких типів [20, 21].

Для формування баз знань (БЗН) КЕС-СЕУЛ як ознаки опису станів Д50 були обрані оцінки спектра, для чого виконувався перехід від часового діапазону сигналів до частотного (перетворення Фур'є). Саме комбінації спектральних характеристик сигналів формували вектори ознак станів двигуна для моделі класифікації, яка представляла БЗн. Для перетворення показників часу отриманих сигналів таким чином, щоб вони коливались навколо нуля, виконувався перехід від часових до дельта-сигналів [18, 22], тобто шляхом згортки сигналу вікном [1, -1]. Новий утворений сигнал відображає зміну - на скільки проходження даного проміжку часу було довшим або коротшим у часі в порівнянні з минулим імпульсом. Встановлено, що перехід до частотного діапазону за допомогою методу Фур'є дає достатню точність на використаних класифікаторах.

Рис. 44 демонструє відмінність у спектрах для різних станів двигуна, як відбиток дельта-часу обертання КВД.
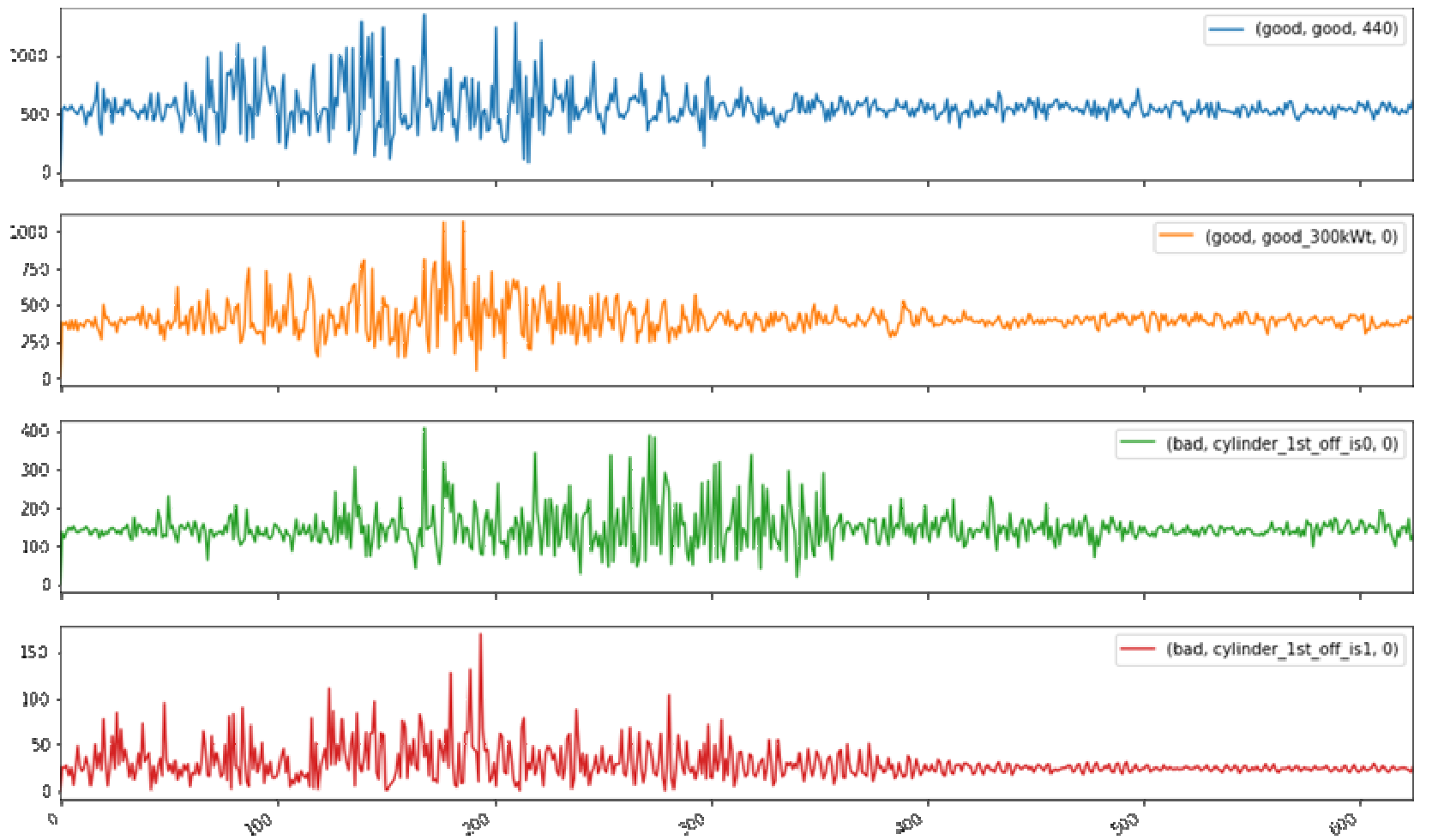

Рис. 4. Графіки спектра на дельта-сигналах різних станів двигуна

\section{Формування автоматичного конвесра класифікації станів СЕУЛ}

Для класифікації станів СЕУЛ був спроектований та реалізований автоматичний конвеєр моделей (АКМ). Конвеєр на основі міри F1-score [18] забезпечує пошук найбільш якісної комбінації вектора ознак і моделі класифікації, придатних для підбору моделі класифікації станів двигунів. Таке завдання реалізується за рахунок комбінації методів формування моделі класифікації, а також оцінювання значень ऑiі гіперпараметрів. На рис. 5 зображена загальна структурна схема конвеєра АКМ, яка представляє технологію його роботи. Для отримання якісної моделі класифікації, а також необхідних для навчання ознак, на вхід конвеєра необхідно подати набір даних кутової швидкості і три групи методів: правила виділення ознак [19], моделі машинного навчання 3 варіаціями гіперпараметрів i кількостей перехресних пошуків [20] та методи оцінювання якості класифікації [21]. Для більш ефективного використання множини ознак конвеєр дає можливість формування обмежень, неприклад, задавати ознаки, що не можуть використовуватися разом. Наприклад, не будуть братись спектральні характеристики на основі статистичних оцінок часових сигналів.

На кожному етапі конвеєра, крім кластерного аналізу, формується нове представлення даних. Задача апарату кластерного аналізу - виконати відсіювання 
тих ознак, що не забезпечують кластерного розподілу. В даному дослідженні кластерний аналіз був виконаний у напівавтоматичному режимі, а саме: будувались проекції на основі TSNE алгоритму [23] у двовимірний простір. У подальшому на основі таких зображень відкидалися ті ознаки, що не виконують якісного кластерного розбиття. Цей етап дозволив скоротити час виконання конвеєра, оскільки побудова деяких моделей класифікації виконується значно довше, ніж операції проектування. Додатково до зазначених процедур був доданий етап накладення кластерів на маркери, що відкривало можливості застосування класифікаторів на основі метричного розподілу. Для спрощення оцінювання процесів автоматичного конвеєра моделей АКМ відповідні результати відображались у вигляді діаграми розсіювання (рис. 6). У КЕС-СЕУЛ також передбачено можливість пошуку ефективної моделі класифікації станів за декількома критеріями, що реалізовано в напівавтоматичному режимі, коли остаточний компроміс критеріїв визначається експертом.

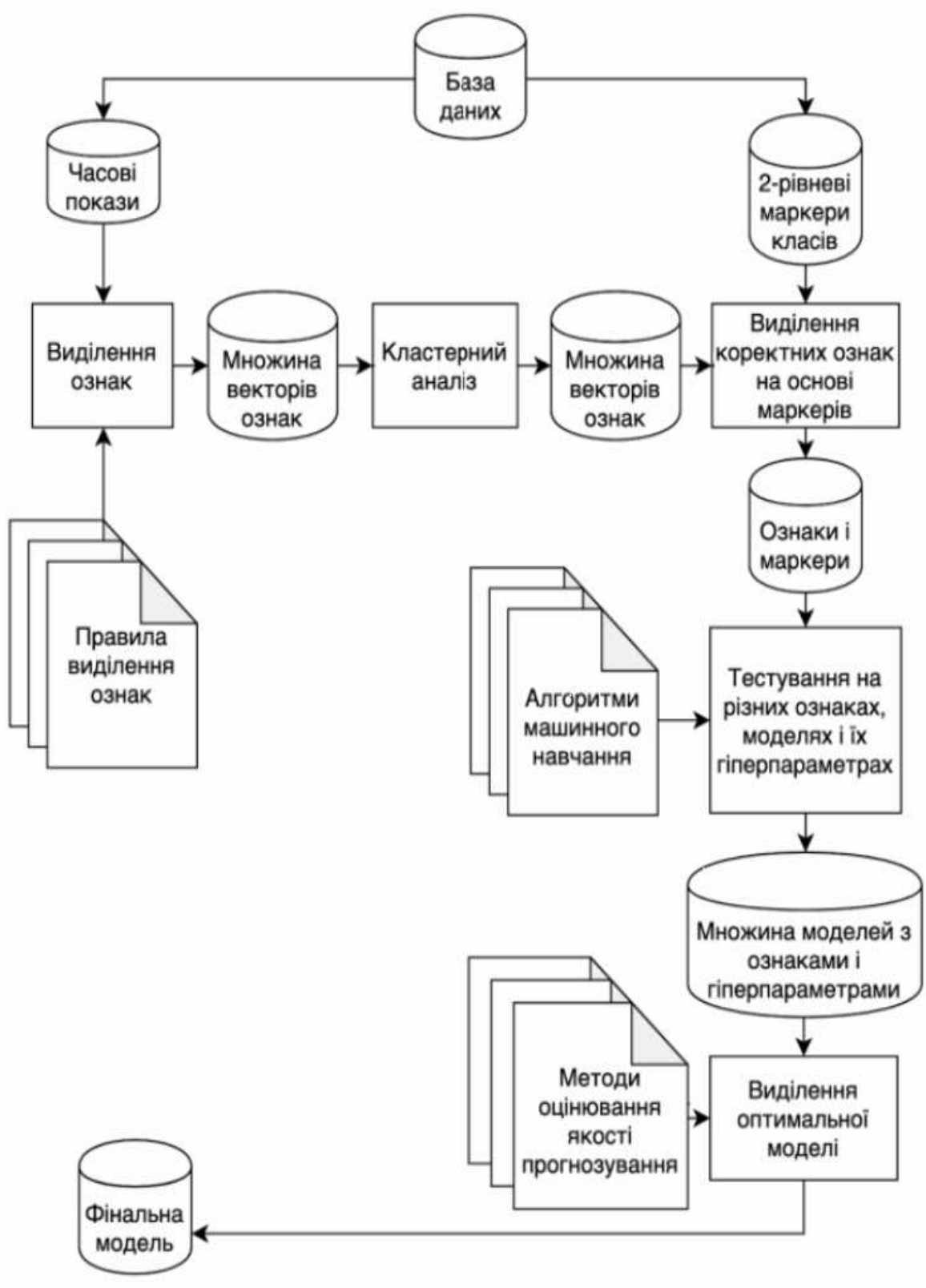

Рис. 5. Схема конвеєра з пошуку оптимальної комбінації вектора ознак і моделі класифікації станів двигунів 


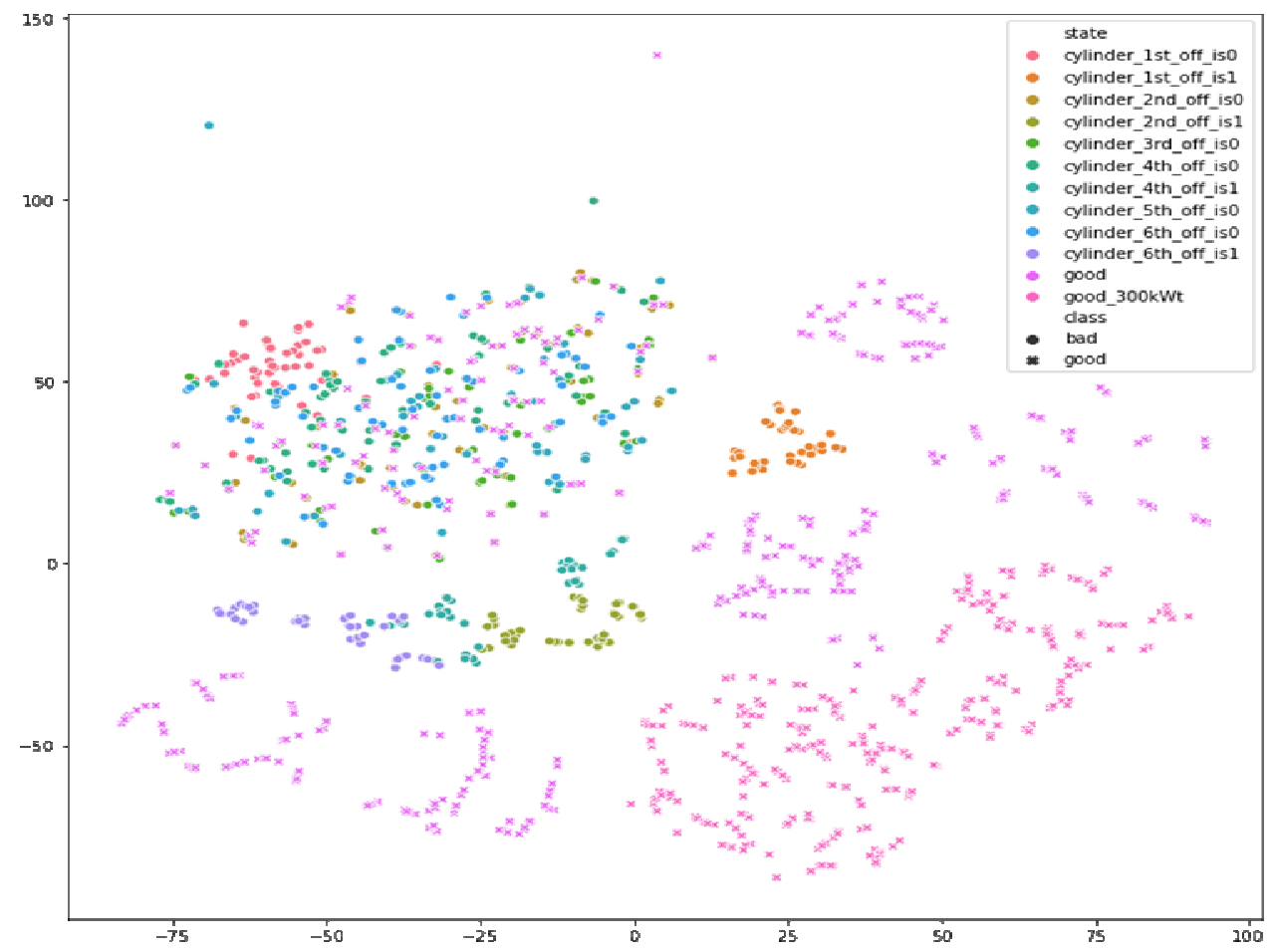

Рис. 6. Зображення розсіювання спектра згорнутого вікном $[1 ;-1]$ сигналу у двовимірному просторі

Зазначимо, що при функціонуванні АКМ за даними про параметри СЕУЛ, автоматично як головна виділена ознака був обраний спектр згорнутого вікном [1; -1] сигналу. На рис. 4 зображено приклад спектра для 4 різних класів. Рис. 4 показуе, що більшість спектра знаходиться в межах низьких $\mathrm{i}$ середніх частот, але іноді деякі особливості процесів проявляються на низьких частотах.

$\mathrm{y}$ роботі для оцінки поточних станів досліджуваного об'єкта запропоновано використання радарних графіків [17], що показують, якому класу несправності (або жодному) відповідає поточний стан СЕУЛ (рис. 7). За площею отриманої фігури зазначений вид графіка дозволяе досить явно представити ступінь невизначеності системи, в тому числі для випадків, навіть якщо фігура розтягнеться між декількома класами станів. Рис. 7 демонструє, що контрольованій системі відповідає високий ступінь впевненості щодо визначеності характеристик іiі поточного стану.

У роботі на основі визначеної конвеєром АКМ множини ознак для працездатних та інших станів СЕУЛ були побудовані відповідні ім моделі логістичної регресії, за якими були реалізовані бінарні та багатокласові класифікації станів вузлів ТРС [19].

Основною моделлю для вирішення задачі оцінювання та прогнозування стану СЕУЛ була обрана логістична регресія (1) з таких причин: відсутність схильності до перенавчання; можливість регуляризації та модифікації для отримання більш складних границь рішень; високий ступінь достовірності інтерпретації.

$$
Y=\left\{\begin{array}{ll}
0, & y^{*} \leqslant 0 \\
1, & y^{*}>0
\end{array},\right.
$$

де $y^{*}=\theta^{T} x=\theta_{0}+\theta_{1} x_{1}+\ldots+\theta_{n} x_{n}+\varepsilon$.

Важливою особливістю класифікатора (1) $є$ можливість розділяти область лише бінарно. Тому для вирішення багатокласової класифікації в роботі будується множина логістичних функцій, які вирішують цю проблему за методом OVR (один проти всіх). При класифікації OVR обирається належність до того класу, де ступінь належності вище, тоді як у випадку OVO (один проти одного) обирається той клас, який отримав найбільшу кількість належностей на свою користь. 


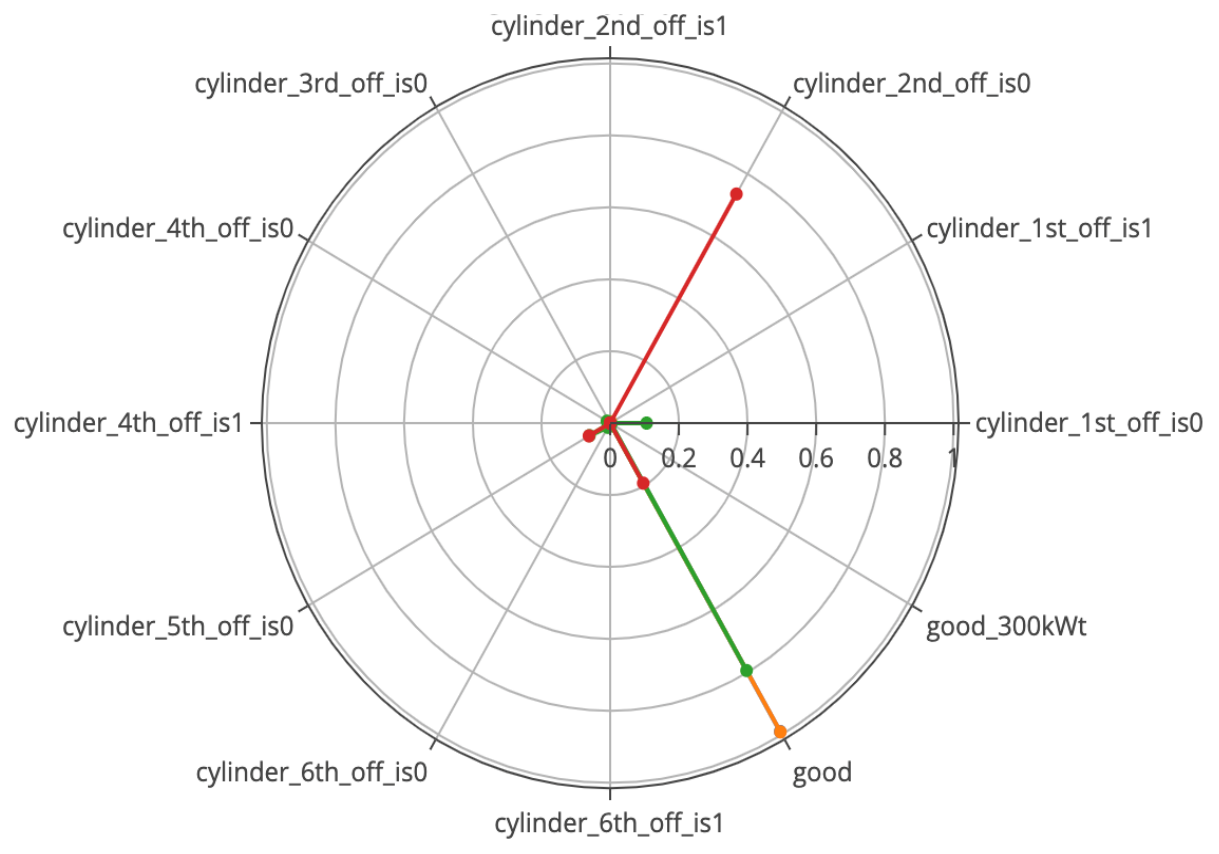

Рис. 7. Радарний графік визначення поточного стану СЕУЛ

Наведемо властивості отриманих моделей класифікації. Властивості моделі бінарної класифікації: $\mathrm{C}=10$, class_weight $=\{$ 'bad': 0.25 , 'good': 0.75$\}$, dual=False,

fit_intercept=True, intercept_scaling=1, 11_ratio=None, $\quad$ max_iter=1000, multi_class='ovr', $\mathrm{n} \_$jobs=None, penalty $=' 12$ ', random_state $=$ None,

solver='lbfgs', tol=0.0001

Властивості моделі багатокласової класифікації:

$\mathrm{C}=100$, class_weight $=$ None, dual=False, fit_intercept=True,

intercept_scaling=1, 11_ratio=None, max_iter=1000,multi_class='ovr',

$\mathrm{n} \_$jobs=None, penalty='12', random_state=None, solver='lbfgs',

tol $=0.0001$

Результуючі моделі, побудовані на основі конвеєра рис. 5, отримали високі значення точності: бінарна класифікація - 97,19 \%, багатокласова - 89,97\%. Оскільки для бінарної класифікації проводилася корекція на тип помилки, то табл. 2 показує, що помилки другого роду відсутні на тестуванні.

Таблиця 2

\section{Матриця неточностей для бінарної класифікації}

\begin{tabular}{|c|c|c|c|}
\hline & & $\begin{array}{l}\text { Відхилення } \\
\text { наявні }\end{array}$ & $\begin{array}{l}\text { Відхилення } \\
\text { відсутні }\end{array}$ \\
\hline \multirow{2}{*}{ 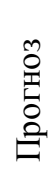 } & $\begin{array}{l}\text { Відхилення } \\
\text { наявні }\end{array}$ & 117 & 5 \\
\hline & $\begin{array}{l}\text { Відхилення } \\
\text { відсутні }\end{array}$ & 0 & 58 \\
\hline
\end{tabular}

У табл. 2 головна діагональ показує правильно класифіковані зразки, на другорядній - показані помилки першого і другого роду.

Визначені в роботі оцінки станів СЕУЛ та моделі виявилися придатними для побудови баз знань КЕССЕУЛ класифікації станів ТРС.

У програмному комплексі КЕС-СЕУЛ також застосовані та реалізовані методи корекції помилок класифікації СЕУЛ для бінарної класифікації [21], що забезпечує підвищення експлуатаційної надійності системи прогнозування станів установок ТРС. Вони надають можливості подальшого застосування моделей класифікації для оптимізації показників економічних і часових витрат процесів експлуатації. Така корекція будувалась на основі мінімізації помилки першого роду i введення цієї оцінки як додаткового методу оцінювання якості моделі.

Оцінки показників точності кожної моделі були інтерпретовані на основі ймовірнісного методу [18], 
що забезпечило можливість встановити значущість певних характеристик сигналів, стосовно завдань класифікації. Як підсумок визначені у роботі оцінки станів СЕУЛ виявилися придатними для побудови баз знань експертної системи класифікації станів ТРС.

Для наочного відображення результатів експертного висновку в КЕС-СЕУЛ застосоване представлення у формі лінії тренду стану СЕУЛ, як подано на рис. 8. При цьому тренд відображає характеристики станів як «за історією розвитку», за часом, так і за бінарними ознаками - «справний/ні».
Для формування таких лінії трендів необхідно виконувати накопичення історичних даних. Графік тренду за побудовою дозволяє відповідати на питання: чи $є$ відхилення в роботі двигуна (значення нижче 0,5 ) або, навпаки, немає (значення вище 0,5). Якщо накопичувати певні повторення результатів діагностування станів СЕУЛ, тоді лінії тренду такого вигляду легко забезпечують можливості прогнозування станів контрольованих систем на певний період.

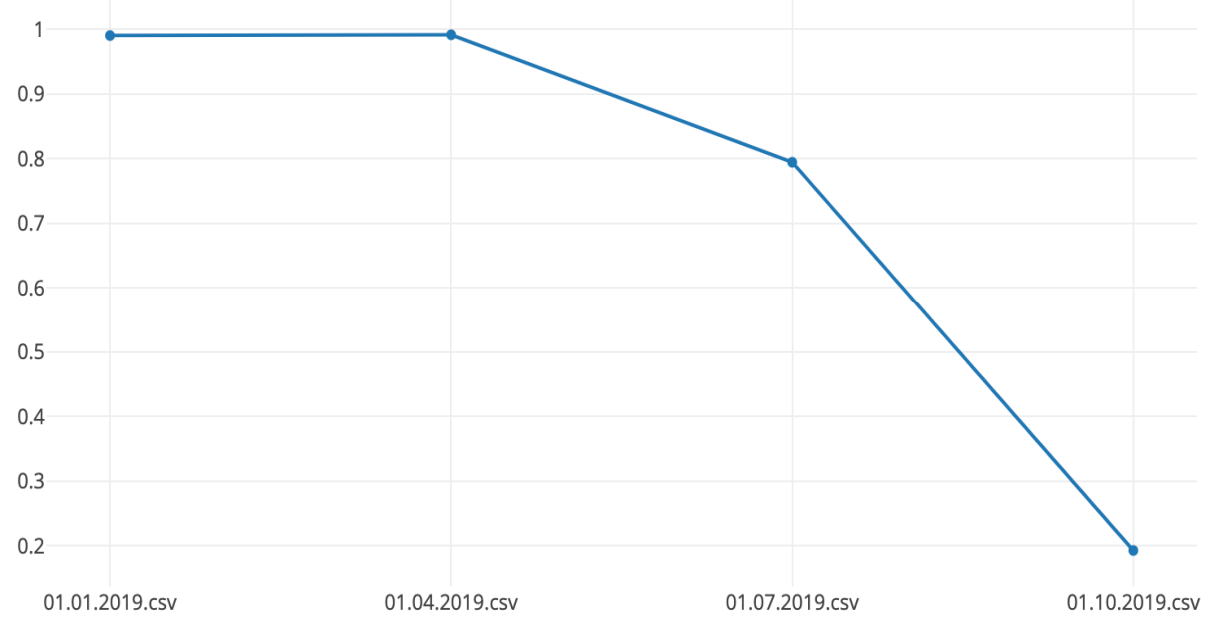

Рис. 8. Історичний тренд стану СЕУЛ

\section{Висновки}

У статті вирішується завдання щодо створення засобів 3 удосконалення та автоматизації процесів експлуатації парків локомотивів, зокрема СЕУЛ, шляхом запровадження сучасних інтелектуальних АСУ ЗТУ. В роботі досліджено можливості створення експертного комплексу КЕС-СЕУЛ, що використовує сигнали кутової швидкості обертів колінчатого вала локомотивів. Комплекс КЕС-СЕУЛ реалізує базові завдання щодо побудови системи аналізу, діагностування та прогнозування стану СЕУЛ. Завдання експертизи реалізуються шляхом поєднання методів цифрової обробки сигналів, статистичного аналізу, класифікації та використання емпіричних знань експертів. У комплексі було автоматизовано завдання 3 визначення множин ознак станів та побудови ефективних моделей логістичної регресії, призначених для класифікації станів СЕУЛ. Формування моделей класифікації організовано 3 перехресним пошуком i підбором параметрів. Найкращі за точністю класифікації станів СЕУЛ моделі поєднуються в ансамбль (відповідно до кожного класу ознак) і утворюють базу знань моделей класифікації. Оцінки кожної моделі були інтерпретовані на основі ймовірнісного методу, що
\end{abstract}

забезпечило можливість встановити значущість певних характеристик сигналів, стосовно завдань класифікації.

Встановлено, що запропоновані в роботі методи 3 оцінки нерівномірності сигналів кутової швидкості обертів колінчатого вала, класи станів СЕУЛ, моделі аналізу, діагностування та прогнозування стану виявилися придатними для побудови баз знань КЕССЕУЛ та виконання класифікації станів ТРС.

Перспективними напрямками подальших досліджень та розробок щодо використання характеристик нерівномірності кутової швидкості обертів колінчатого вала (інших елементів конструкцій ТРС) для завдань діагностування, аналізу та прогнозування станів вузлів локомотивів $€$ такі: використання інших категорій експертної інформації, дослідження інших технічних систем, розробка інтелектуальних процедур аналізу накопичуваної інформації та планування моніторингу ТРС.

\section{Список використаних джерел}

1. Скалозуб В. В., Цейтлин С.Ю., Чередниченко М. С. Интеллектуальные информационные технологии и системы железнодорожного транспорта. Монограф. «Системные технологии моделирования сложных 
проиессов». Днепр: НМетАУ - ИВК «Системные технологии», 2016. С. $560-589$.

2. Жуковицький І. В., Скалозуб В. В., Устенко А. Б. Інтелектуальні засоби управління парками технічних систем залізничного транспорту. Монографія. Дніпро: Вид-во ПФ «Стандарт Сервіс», 2018. $190 \mathrm{c.}$

3. Скалозуб В. В., Швец О. М., Осовик В. Н. Методы интеллектуальных транспортных систем в задачах управления парками объектов железнодорожного транспорта по текущему состоянию. 3б. наук. праџь ДНУ ім. О. Гончара «Питання прикладної математики $i$ математичного моделювання». Дніпропетровськ: Вид-во «Ліра», 2014. С. 229 242.

4. Скалозуб В. В., Жуковицкий И. В., Клименко И. В. Создание интеллектуальных систем поддержки принятия решений в единой автоматизированной системе управления грузовыми железнодорожными перевозками Украины. Системні технології. Дніпро, 2018. 3(116). С.153-162.

5. Zhukovyts'kyy I. Use of an automaton model for the designing of real-time information systems in the railway stations. Transport problems. 2017. T. 12. Z. 4. P.101-108.

6. Ontology-Based Classification System Development Methodology / P. Grabusts, A. Borisov, L. Aleksejeva. Information Technology and Management Science. 2015. Vol. 18, Issue 1. P. 129-134. doi: $10.1515 /$ itms2015-0020

7. Development of ontological support of constructivesynthesizing modeling of information systems/ V. Skalozub, V. Illman, V. Shynkarenko. EasternEuropean Journal of Enterprise Technologies. 2017. Vol. 6/4 (90). P. 58-69. doi: 10.15587/17294061.2017.119497

8. Ontological support formation for constructivesynthesizing modeling of information systems development processes / V. Skalozub, V. Illman, V. Shynkarenko. Eastern-European Journal of Enterprise Technologies. 2018. Vol. 5/4 (95). P. 55-63.

9. Пегат А. Нечеткое моделирование и управление / пер. с англ. Москва: БИНОМ. Лаборатория знаний, 2009. $798 \mathrm{c}$.

10. Айфичер Э. С., Джервис Б. У. Цифровая обработка сигналов: практический подход. Изд 2-е. Москва: Вильямс, 2008. 992 с.

11. Нуссбаумер Г. Быстрое преобразование Фурье и алгоритмы вычисления сверток/ пер. с англ. Москва: Радио и связь, 1985. 382 с.

12. Боднар Б. Є., Очкасов О. Б., Черняєв Д. В., Децюра О. Я. Моделювання нерівномірності обертання колінчатого вала дизеля. Вісник Дніпропетр. нац. ун-ту залізнич. трансп. ім. акад. B. Лазаряна. Дніпропетровськ: ДНУЗТ, 2010. Вип. 31. С. 18-25.
13. Методи нерозбірного діагностування дизелів при експлуатації рухомого складу /Б. С. Боднар, О. Б. Очкасов, О. Я. Децюра, Д. В. Черняєв. Вісник Дніпропетр. нач. ун-ту залізнич. трансп. ім. акад. B. Лазаряна. Дніпропетровськ, 2012. Вип. 41. C. $56-60$.

14. Боднар Б. Є., Очкасов О. Б., Черняєв Д. В. Визначення методу фільтрації сигналу нерівномірності частоти обертання колінчастого вала дизеля. Наука та прогрес транспорту. 2013. № 1. C. 123-118.

15. Use of the Wavelet Transform for the Analysis of Irregularity of Crankshaft Angular Velocity / B. Bodnar, O. Ochkasov, D. Chernyaev, R. Skvireckas. Transport Means 2018: Proc. of the 22nd Intern. Sci. Conf. (Oct. 03-05, 2018, Trakai, Lithuania) / Kaunas Univ. of Technology, Klaipéda Univ., JSC Lithuanian Railways (AB "Lietuvos Geležinkeliai") [et al.]. Kaunas, 2018. Pt. II. P. 962-967.

16. Ochkasov, O. Usage of Intelligent Technologies in Choosing the Strategy of Technical Maintenance of Locomotives / O. Ochkasov, O. Shvets, L. Černiauskaitè. Technologijos ir Menas = Technology and Art. 2017. № 8. C. $68-71$.

17. E. Webb, "Find Content Gaps Using Radar Charts," 03 03 2015. [Online]. Available: http://www.contentworkshops.com/toolbox/2015/2/find-content-gapsusing-radar-charts.

18. "F1 score," 3011 2019. [Online]. Available: https://en.wikipedia.org/wiki/F1_score.

19. M. Ved, "Feature Selection and Feature Extraction in Machine Learning: An Overview," 1972018. [Online]. Available: https://medium.com/@mehulved1503/featureselection-and-feature-extraction-in-machine-learningan-overview-57891c595e96.

20. S. M., "Why and how to Cross Validate a Model?," 13 $112018 . \quad$ [Online]. Available: https://towardsdatascience.com/why-and-how-to-crossvalidate-a-model-d6424b45261f

21. "Metrics and scoring: quantifying the quality of predictions," scikit-learn developers , [Online]. Available: https://scikitlearn.org/stable/modules/model_evaluation.html.

22. L. Derksen, "Visualising high-dimensional datasets using PCA and t-SNE in Python," 29102016. [Online]. Available: https://towardsdatascience.com/visualising-highdimensional-datasets-using-pca-and-t-sne-in-python8ef87e7915b

23. David W. Hosmer, Jr., Stanley Lemeshow, Rodney, Applied Logistic Regression, John Wiley \& Sons Inc., 2013.

24. Джарратано Д., Райли Г. Экспертные системы. Москва: ООО «И. Д. Вильямс», 2007. 1152 с. 
Скалозуб В. В., Очкасов А. Б., Кибец Д. В. Автоматизированный экспертный комплекс для исследования и прогнозирования параметров силовых энергетических установок локомотивов.

Аннотация. В статье исследованы возможности создания и результаты применения автоматизированного экспертного комплекса, предназначенного для решения задач по усовершенствованию эксплуатации парков локомотивов, которые реализуются методами современных интеллектуальных систем. Процедуры мониторинга и диагностирования обеспечивают реализацию задач контроля параметров функционирования силовых энергетических установок локомотивов (СЕЭЛ). Комплекс экспертной системы (КЭС-СЭУЛ) реализует базовые задания по формированию системы анализа, диагностирования и прогнозирования состояний СЭУЛ на основе сигналов угловой скорости вращения коленчатых валов. В КЭССЭУЛ задания экспертизы реализуются путем объединения методов цифровой обработки сигналов, статистического анализа, классификации и использования эмпирических знаний экспертов. Приводятся структура, модели и результаты диагностирования СЭУЛ.

Ключевые слова: силовая энергетическая установка, локомотив, угловая скорость вращения, коленчатый вал, интеллектуальные автоматизированные системы, диагностирование, прогнозирование, логистическая регрессия.

Skalozub V. V., Ochkasov A. B., Kybec D. V. Automated expert system for research and forecasting of the locomotive power facilities parameters.

Abstract. The article describes the possibilities of creation and the results of the automated expert complex using, which is designed to solve improving problems of the locomotive fleets operation, which are implemented using modern intelligent systems. Monitoring and diagnostic procedures provide the implementation of the controlling tasks of the locomotive power facilities (LPF) functioning parameters. The expert system complex (ESC-LPF) implements the basic tasks of creating a system for analyzing, diagnosing and predicting the state of LPF based on signals of the angular speed of the crankshafts rotation. In ESC-LPF expertise tasks are implemented by combining methods of digital signal processing, statistical analysis, classification and the use of empirical experts' knowledge. The structure, models and results of diagnosing LPF are given.

Keywords: power plant, locomotive, angular rotation speed, crankshaft, intelligent automated systems, diagnostics, forecasting, logistic regression.
Скалозуб Владислав Васильович, доктор технічних наук, професор, декан факультету технічної кібернетики. Дніпровський національний університет залізничного транспорту імені академіка В. Лазаряна, Дніпро, Україна. E-mail: skalozub.vl.v@gmail.com, http://orcid.org/0000-0002-1941-4751

Очкасов О. Б., кандидат технічних наук, доцент, дочент кафедри локомотивів. Дніпровський національний університет залізничного транспорту імені академіка В. Лазаряна, Дніпро, Україна. E-mail: abochkasov@gmail.com, _ http://orcid.org/0000-00027719-7214

Кібець Д. В., магістр. Дніпровський національний університет залізничного транспорту імені академіка В. Лазаряна, Дніпро, Україна. E-mail: dima.kibetc@gmail.com, https://orcid.org/0000-0002$\underline{1901-9110}$

Skalozub Vladislav, Doctor of engineering, Professor, Dean of the Faculty of Technical Cybernetics, Dnipro National University of Railway Transport named after academician Lazaryan, Dnipro, Ukraine. E-mail: skalozub.vl.v@gmail.com, $\quad$ http://orcid.org/0000-00021941-4751

Ochkasov Oleksandr, PhD of technical science, associate professor of "Locomotives" subdepartment, Dnipro National University of Railway Transport named after academician Lazaryan, Dnipro, Ukraine. E-mail: abochkasov@gmail.com, http://orcid.org/00000002-7719-7214

Kibets Dmytro, master degree of software engineering, Dnipro National University of Railway Transport named after academician Lazaryan, Dnipro, Ukraine. E-mail:dmkibets@gmail.com, https://orcid.org/0000-0002-1901-9110 